\author{
MICHAŁ ZIELEZNY \\ Uniwersytet Śląski
}

\title{
Tzw. usiłowanie kwalifikowane - próba nowego spojrzenia
}

\begin{abstract}
In the doctrine of criminal law, the term "qualified attempt" denotes two cases. Firstly, the term "qualified attempt" describes a situation in which, when the perpetrator, in their intent to commit a criminal act, directly aims to commit it but does not succeed (attempt), while fulfilling all premises of another criminal act (commission). In the second case, the term "qualified attempt" describes a situation in which the attempt at the commission of a criminal act is covered by the impunity clause on the basis of active grief, while the act of the perpetrator needs to be classified as a commission of a different criminal act. The article, following a general overview of the literature on the subject, presents the author's own understanding of the term "qualified attempt", which consists in the differentiation among attempt, cumulatively qualified attempt with commission, and non-punishable attempt subsumed as a punishable commission.
\end{abstract}

Key words: qualified attempt, attempt, stages of delict, concurrence of provisions, actual concurrence of provisions, rules of exclusion of multiple evaluation

Celem niniejszego artykułu jest próba nowego spojrzenia na problematykę tzw. usiłowania kwalifikowanego. Instytucja ta od dawna jest $\mathrm{w}$ orbicie zainteresowania doktryny prawa karnego, jednak wypowiedzi na jej temat bywają lakoniczne i brak jest szerszego opracowania problemu. Może to wynikać z tego, że stan faktyczny, w którym sprawca jednym czynem zrealizował znamiona usiłowania jednej typizacji, a zarazem tym samym czynem zrealizował znamiona innego czynu zabronionego, jest de facto sytuacją, gdy czyn sprawcy zrealizował znamiona dwóch lub więcej typizacji, czyli jest oceniany przez pryzmat zbiegu przepisów. Wyjątkowość usiłowania kwalifikowanego polega na tym, że zbiegają się dwie różne formy popełnienia czynu zabronionego, tj. usiłowanie i dokonanie, podczas gdy w typowej sytuacji zbiegu przepisów czyn zabroniony, 
którego dopuścił się sprawca, jest zazwyczaj dokonaniem. Przed przedstawieniem własnego stanowiska należy przytoczyć poglądy doktryny $\mathrm{w}$ przedmiotowej materii.

W. Wolter w 1973 roku wyraził pogląd, że: „z istoty usiłowania wynika, że czyn w miarę zbliżania się ku dokonaniu może przebiegać przez pewne stadia, które już same dla siebie mogą być kwalifikowane jako dokona-

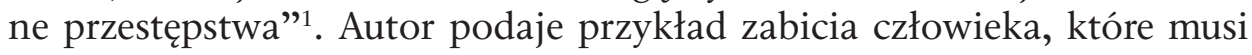
przebiegać przez stadium uszkodzenia ciała lub rozstroju zdrowia. Jeżeli przestępstwo zostało dokonane, poprzedzające stadia nie są interesujące. Inaczej będzie się rysować odpowiedzialność sprawcy, jeżeli jego czyn zakończył się na usiłowaniu. W. Wolter rozumiał usiłowanie kwalifikowane jako usiłowanie kwalifikowane przez zawarte $\mathrm{w}$ nim dokonanie innego przestępstwa. Są to dwa przypadki: gdy sprawca usiłował popełnić jedno przestępstwo, a zawiera się $\mathrm{w}$ nim dokonanie innego, oraz gdy sprawca nie poniesie odpowiedzialności za usiłowanie na podstawie czynnego żalu, ale poniesie odpowiedzialność za zawarte w nim dokonanie innego przestępstwa ${ }^{2}$. Przykładem pierwszego przypadku - zdaniem tego autora - usiłowania kwalifikowanego jest sytuacja, gdy sprawca chciał zabić człowieka, a spowodował tylko ciężki uszczerbek jego zdrowia. W takiej sytuacji należy przyjąć kumulatywną kwalifikację usiłowania zabójstwa ze spowodowaniem ciężkiego uszczerbku zdrowia, ponieważ przyjęcie samego usiłowania bez kumulatywnej kwalifikacji może być niewystarczające $^{3}$. Przykładem drugiego przypadku usiłowania kwalifikowanego jest sytuacja, gdy sprawca chciał otruć drugą osobę, następnie dobrowolnie zapobiegł wystąpieniu skutku śmiertelnego, jednak nie udało mu się zapobiec długotrwałej, ciężkiej chorobie. Zdaniem W. Woltera jeżeli sprawca miał zamiar zabicia człowieka, to implicite ma zamiar spowodowania stadiów poprzedzających zabicie. Jeżeli więc na podstawie czynnego żalu sprawca nie poniesie odpowiedzialności za usiłowanie zabójstwa, to nic nie stoi na przeszkodzie, by przypisać mu odpowiedzialność karną za dokonane przestępstwo spowodowania uszczerbku na zdrowiu ${ }^{4}$.

K. Buchała i A. Zoll zwracają uwagę, że usiłowanie kwalifikowane łączy się z dwoma rodzajami przypadków. Po pierwsze, jeśli sprawca odpowiada za usiłowanie przestępstwa, to zrealizowanie znamion innego przestępstwa powinno być rozstrzygane na gruncie zbiegów przepisów. Po drugie, jeśli wskutek czynnego żalu sprawca nie ponosi odpowiedzialności, to aktualizuje się jego odpowiedzialność za dokonane po drodze

${ }^{1}$ W. Wolter: Nauka o przestępstwie. Warszawa 1973, s. 275.

2 Ibidem.

3 Ibidem, s. 341.

${ }^{4}$ Ibidem, s. 275-276. Taki sam pogląd wyrażał M. Cieślak, por. M. Cieślak: Polskie prawo karne. Zarys systemowego ujęcia. Warszawa 1990, s. 377 i 379. 
przestępstwa. Autorzy ci jednak zauważają, że wyłączenie odpowiedzialności za usiłowanie nie aktualizuje odpowiedzialności za narażenie dobra prawnego na niebezpieczeństwo, bowiem takie narażenie należy do istoty usiłowania 5 .

W. Radecki przy okazji analizy czynnego żalu zauważa, że skuteczny czynny żal obejmuje tylko usiłowanie, a nie uchyla odpowiedzialności sprawcy za dokonane inne przestępstwo. Autor, powołując się na pogląd S. Śliwińskiego, wysnuł tezę, że w sytuacji, gdyby sprawca podał drugiej osobie truciznę, a następnie odtrutkę, nie ma przeciwwskazań, aby sprawca ten poniósł odpowiedzialność za narażenie życia człowieka na niebezpieczeństwo ${ }^{6}$.

D. Gajdus w swojej monografii na temat czynnego żalu poświęca więcej uwagi przypadkowi, gdy sprawca nie podlega karze za usiłowanie na podstawie czynnego żalu, ale aktualizuje się jego odpowiedzialność za dokonane „po drodze” przestępstwo. Autorka zauważa, że skutki czynnego żalu, czyli bezkarność, jak i depenalizacja, dotyczą tylko tego czynu, na tle którego sprawca objawił czynny żal. Zdaniem autorki nie wyłącza to jednak ani możliwości, ani konieczności przypisania sprawcy czynu już dokonanego w chwili, gdy sprawca ten od dokonania innego przestępstwa odstępuje. Zdaniem D. Gajdus dobrowolne odstąpienie lub dobrowolne zapobieżenie skutkowi przestępnemu nie oznacza całkowitego wyłączenia odpowiedzialności sprawcy usiłowania, lecz tylko za ten skutek, który usiłował spowodować i któremu zapobiegł. W tej sytuacji sprawca ponosi odpowiedzialność karną za inne skutki, które nie są objęte czynnym żalem7.

A. Wąsek usiłowanie kwalifikowane łączy z wypadkiem wyłączenia odpowiedzialności karnej za usiłowanie na podstawie czynnego żalu, co jednak nie sprzeciwia się pociągnięciu sprawcy do odpowiedzialności karnej za dokonane jakoby „po drodze” przestępstwo. Autor ten podziela stanowisko K. Buchały i A. Zolla, według którego skuteczny czynny żal w przypadku usiłowania zabójstwa nie aktualizuje odpowiedzialności za narażanie życia i zdrowia człowieka na niebezpieczeństwo. Narażenie takie łączy się zazwyczaj z usiłowaniem zabójstwa ${ }^{8}$.

${ }^{5}$ K. Buchata, A. Zoll: Polskie prawo karne. Warszawa 1995, s. 289.

6 W. Radecki: Prawne i moralne oceny czynnego żalu. Pal. 1976, nr 12, s. 26-27.

7 D. GajDus: Czynny żal w polskim prawie karnym. Toruń 1984, s. 188 . Taki sam pogląd wyrażali: A. Gubiński, por. A. GuBiński: Zasady prawa karnego. Warszawa 1974, s. 69; I. Andrejew, por. I. ANDREjew: Prawo karne. Warszawa 1989, s. 242; W. Świda, por. W. Świda: Prawo karne. Warszawa 1989, s. 194; Cz. Gofroń, por. Cz. Gofroń. W: Prawo karne. Red. T. BOJARSKI. Lublin 1994, s. 190-191.

8 A. WĄSEK: Kodeks karny. Komentarz. T. I: art. 1-31. Gdańsk 1999, s. 218; podobnie: L. GARDOCKI: Prawo karne. Warszawa 2011, s. 111. 
T. Bojarski rozumie usiłowanie kwalifikowane jako sytuację, gdy sprawca zmierzając do naruszenia jednego dobra prawnie chronionego, de facto uszkadza inne dobro. Autor ten zauważa, że jest to charakterystyczne dla przestępstw przeciwko życiu i zdrowiu. Zgłasza on wątpliwość, czy w wypadku, gdy sprawca usiłuje zabić drugiego człowieka, realizuje znamiona uszkodzenia ciała, należy przyjąć kumulatywną kwalifikację, czy też wystarczy poprzestać na zakwalifikowaniu czynu jako usiłowanie zabójstwa ${ }^{9}$. T. Bojarski opowiada się za poglądem, że w takiej sytuacji należy przyjąć kumulatywną kwalifikację usiłowania zabójstwa z uszkodzeniem ciała ${ }^{10}$.

R. Zawłocki uważa, że w przypadku, gdy sprawca zamierza zrealizować/spowodować określony skutek, a nie powoduje go, to można zastosować kumulatywną kwalifikację usiłowania jednego przestępstwa z dokonaniem innego. Warunkiem takiej kwalifikacji, zdaniem tego autora, jest realne wypełnienie przedmiotowych i podmiotowych znamion czynów zabronionych, określających zbiegające się przestępstwa. Wywołanie skutku „wtórnego" powinno być objęte zamiarem sprawcy, chociażby miał to być zamiar ewentualny. Autor ten podnosi, że „w tym znaczeniu sprawca zamierzał wywołać różne skutki, dalsze oraz bliższe, jak i odwrotnie - bliższe oraz "przy okazji« również dalsze. W takiej sytuacji kumulatywna kwalifikacja jest uzasadniona, ale nie przesądzona, ponieważ przepisy [...] mogą pozostawać w bezwzględnym (formalnym) zbiegu pozornym"11. Konieczne jest rzetelne ustalenie stanu faktycznego, gdzie będzie możliwa pełna i jednoznaczna rekonstrukcja stosunku psychicznego sprawcy do jego czynu. R. Zawłocki zauważa, że nierzadko zdarzają się przypadki, gdy sprawca nie zrealizował $\mathrm{w}$ pełni swojego zamiaru, a tym samym czynem naruszył inne dobro prawnie chronione. Kumulatywna kwalifikacja powinna mieć miejsce, jeżeli sprawca rzeczywiście zrealizował znamiona typizacji chroniącej to inne dobro prawne. „Jeżeli jednak tak »popełniony « czyn zabroniony stanowi w istocie pośredni i konieczny etap "pochodu przestępstwa «sprawcy, to nie może być powołany w kwalifikacji karnoprawnej jego zachowania" ${ }^{12}$. Zastosowanie kumulatywnej kwalifikacji, w opinii tego autora, nie może się opierać jedynie na formalnym wystąpieniu dwóch przepisów. Rozstrzygające ma być to, czy te przepisy będą się odnosiły do tego samego zamiaru sprawcy. R. Zawłocki uważa, że w wypadku uszkodzeń ciała w wyniku usiłowania zabójstwa

9 T. Bojarski: Polskie prawo karne. Warszawa 2008, s. 203-204.

10 T. BojarsKi. W: IDEM: Kodeks karny. Komentarz. Warszawa 2008, s. 56.

11 R. ZawŁocki. W: Kodeks karny. Część ogólna. Komentarz do art. 1-31. T. I. Red. M. KróLIKowsKi, R. ZawŁocKI. Warszawa 2011, s. 547.

12 Ibidem. 
nie będzie miała miejsca kumulatywna kwalifikacja ${ }^{13}$. Uważa on również, że dobrodziejstwo art. $15 \S 1$ k.k. ma zastosowanie tylko do usiłowania. W sytuacji kumulatywnej kwalifikacji usiłowania (czyli skutków dalej idących) i dokonania (skutków zrealizowanych „po drodze”) czynny żal będzie skutkował umorzeniem postępowania tylko do czynu ocenianego jako usiłowanie ${ }^{14}$.

W. Wróbel i A. Zoll usiłowaniem kwalifikowanym nazywają sytuację, gdy sprawca usiłujący dokonać czynu zabronionego może „po drodze” tym samym czynem zrealizować znamiona innego czynu ${ }^{15}$. W takiej sytuacji należy zastosować kumulatywną kwalifikację usiłowania z dokonaniem. W sytuacji, gdy czynny żal wyłączy karalność usiłowania, sprawca powinien być pociągnięty do odpowiedzialności karnej za wywołane swoim działaniem skutki. Autorzy ci zgłaszają wątpliwość co do strony podmiotowej czynu. „Sprawca nie działał bowiem w zamiarze spowodowania uszczerbku [autorzy podają przykład sprawcy, który skutecznie zapobiegł skutkowi śmiertelnemu, ale tym samym czynem spowodował uszczerbek na zdrowiu - M.Z.]. Odnośnie do strony podmiotowej byłaby wskazana wyraźna wypowiedź ustawodawcy, pozwalająca na przypisanie w takim wypadku umyślności spowodowania skutku lżejszego od pierwotnie zamierzonego. Bez takiej wypowiedzi przyjmowanie umyślności, co występuje w praktyce, nie ma wyraźnej podstawy, ani faktycznej, ani prawnej" ${ }^{16}$. Wyłączenie karalności usiłowania obejmuje wszystko to, co jest integralną częścią usiłowania. Sprawca, który dobrowolnie odstąpił od dokonania zabójstwa, nie odpowiada za narażanie życia na bezpośrednie niebezpieczeństwo ${ }^{17}$.

Warto w tym miejscu zauważyć, że A. Zoll już wcześniej zgłaszał podobne wątpliwości co do strony podmiotowej przy usiłowaniu kwalifikowanym, ale wobec przyjmowania kumulatywnej kwalifikacji usiłowania $\mathrm{z}$ dokonaniem ${ }^{18}$. Uważa on, że kumulatywna kwalifikacja nie we wszystkich przypadkach będzie uzasadniona (autor ten podaje przykład sprawcy, który w zamiarze spowodowania śmierci strzela z broni palnej do drugiej osoby, co powoduje jedynie ciężki uszczerbek na zdrowiu). Będzie

${ }^{13}$ Ibidem, s. 546-548.

${ }^{14}$ Ibidem, s. 604-605.

15 W. Wróbel, A. Zoll: Polskie prawo karne. Kraków 2010, s. 239.

16 Ibidem, s. 239-240.

17 Ibidem. Podobnie problem ujmują: A. Marek, por. A. MareK: Prawo karne. Warszawa 2005, s. 195 i 197; G. Rejman, por. G. Rejman: Zasady odpowiedzialności karnej. Art. 8-31 KK. Komentarz. Warszawa 2009, s. 232, 294 i 301; M. Mozgawa, por. M. MozgawA. W: Prawo karne materialne. Część ogólna. Red. M. Mozgawa. Warszawa 2011, s. 309, przypis 39.

18 A. Zoll: Zbieg przepisów określających typy czynów zabronionych o zróżnicowanej stronie przedmiotowej. W: Zbieg przepisów oraz zbieg przestępstw w polskim prawie karnym. Materiały II Bielańskiego Kolokwium Karnistycznego. Red. J. MaJEwsKi. Toruń 2006. 
ona dopuszczalna, jeżeli zamiar sprawcy spowodowania śmierci obejmował spowodowanie uszczerbku na zdrowiu. Musiałby to być co najmniej zamiar ewentualny. Zdaniem jednak A. Zolla nie zawsze sprawca chce i przewiduje możliwość spowodowania uszczerbku na zdrowiu - może chcieć zabić, a nie chce ani nie przewiduje powstania skutku w postaci uszczerbku na zdrowiu. W opinii tego autora kumulatywna kwalifikacja nie będzie uwzględniała pełnej strony podmiotowej czynu. A. Zoll uważa także, że nie można się oprzeć na wnioskowaniu argumentum a maiori ad maius, ponieważ zamiaru sprawcy nie można domniemywać, lecz powinien on być udowodniony na podstawie wszystkich okoliczności. Jego zdaniem należy i w takim przypadku przyjmować kumulatywną kwalifikację, ale czynu zabronionego o mieszanej stronie podmiotowej (czyli usiłowania zabójstwa w zbiegu z nieumyślnym spowodowaniem ciężkiego uszczerbku na zdrowiu $)^{19}$.

O. Sitarz, omawiając usiłowanie kwalifikowane, opisuje trzy różne sytuacje. Klasycznym usiłowaniem kwalifikowanym autorka określa sytuację, gdy sprawca zamiast zamierzonego skutku spowodował inny skutek. Kolejną grupę stanowią sytuacje, gdy dokonanie czynu zabronionego musi być poprzedzone naruszeniem innego dobra prawnego. Naruszenie dobra, jak wskazuje autorka, „naturalnie współwystępuje” przy dokonaniu i usiłowaniu. To naruszenie dobra musi być koniecznym etapem do dokonania. Wtedy, zdaniem autorki, nie mamy do czynienia z usiłowaniem kwalifikowanym, a do normatywnego opisu tej sytuacji służy nieuwzględniany zbieg przepisów. O. Sitarz rozróżnia jeszcze jedną grupę, którą stanowią przestępstwa wieloczynowe. W sytuacji, gdy poszczególne elementy przestępstwa wieloczynowego są odrębnymi przestępstwami, tj. przestępstwo złożone, wieloodmianowe, czyn ciągły, wówczas dokonanie z pierwszej z kryminalizowanych czynności jest usiłowaniem i należy skorzystać z konstrukcji usiłowania kwalifikowanego. Natomiast gdy na przestępstwo wieloczynowe składają się elementy, które rozpatrywane osobno nie stanowią odrębnych typizacji, tj. przestępstwa dwuaktowe i zbiorcze, wykonanie pierwszej czynności należy ocenić jako usiłowanie, ale nie ma tutaj miejsca na usiłowanie kwalifikowane ${ }^{20}$. Autorka ostatecznie rozróżnia usiłowanie kwalifikowane jako usiłowanie kwalifikowane, gdzie korzysta się z kumulatywnej kwalifikacji, oraz usiłowanie pozornie kwalifikowane, gdzie należy skorzystać z reguł wyłączenia wielości ocen. O. Sitarz proponuje następujący test: „Można bowiem na potrzeby ustalania rodzaju usiłowania (a zatem i karnoprawnych konsekwencji czynne-

19 Ibidem, s. 90.

20 O. SitARz: Czynny żal związany z usiłowaniem $w$ polskim prawie karnym. Katowice 2015, s. 226-227. 
go żalu) przeprowadzić test, zakładający, że hipotetycznie do dokonania ostatecznie doszło - jeśli w takim przypadku przyjmujemy rzeczywisty zbieg przepisów, prawdopodobnie mamy do czynienia z usiłowaniem kwalifikowanym, zbieg pozorny/pomijalny skłania do przyjęcia konstrukcji usiłowania pozornie kwalifikowanego. Oczywiście taka zależność nie ma charakteru mechanicznego [...] niemniej oddając istotę rzeczy, bardzo ułatwi karnoprawne wartościowanie czynnego żalu" ${ }^{21}$. Autorka zauważa, że w orzecznictwie i doktrynie problem usiłowania kwalifikowanego nie pojawia się przy usiłowaniu zatamowanym. Problem aktualizuje się przy czynnym żalu, gdzie ujawnia się trend, żeby sprawcę skazać „za wszelką cenę", jeśli nie będzie ponosił odpowiedzialności za usiłowanie. Zauważa jednocześnie, że pomija się w tej sytuacji instytucję nieskutecznego czynnego żalu $\mathrm{z}$ art. $15 \$ 2$ k.k. ${ }^{22}$. Zdaniem O. Sitarz nie ma żadnych przeciwwskazań, ażeby w tej sytuacji stosować przepisy art. 15 § 1 k.k. dla przestępstwa usiłowanego oraz $15 \S 2 \mathrm{k} . \mathrm{k}$. dla przestępstwa dokonanego ${ }^{23}$.

W mojej ocenie stany faktyczne, które obejmujemy usiłowaniem kwalifikowanym, to trzy różne sytuacje. Proponuję rozróżnienie usiłowania od usiłowania kumulatywnie kwalifikowanego z dokonaniem oraz od niekaralnego usiłowania subsumowanego jako karalne dokonanie ${ }^{24}$. Pierwszą grupę stanowią sytuacje, gdy sprawca dopuścił się jednego czynu, który jednocześnie może być oceniony jako usiłowanie i dokonanie, lecz ostatecznie czyn ten zostanie oceniony tylko jako usiłowanie. Dotyczy to przypadków, gdzie znajdą zastosowanie reguły wyłączenia wielości ocen, jak również typizacji, w których do istoty usiłowania czynu zabronionego należy popełnienie innego czynu zabronionego oraz przestępstw wieloczynowych. Jeżeli czyn sprawcy można jednocześnie ocenić jako usiłowanie i dokonanie, to należy sprawdzić, czy można skorzystać z reguł wyłączenia wielości ocen. Oczywiście na pierwszy plan wysuwa się zasada konsumpcji, dlatego że zasada specjalności i subsydiarności ustawowej nie nastręczają problemów i raczej nie mają tutaj zastosowania ${ }^{25}$.

${ }^{21}$ Ibidem, s. 420.

22 Ibidem, s. 421.

${ }^{23}$ Ibidem, s. 479.

${ }^{24} \mathrm{O}$ ocenie niekaralnego usiłowania jako karalnego dokonania pisałem więcej na przykładzie orzeczeń sądowych. M. ZIELEZNY: Bezkarne usiłowanie kwalifikowane jako karalne dokonanie $w$ orzecznictwie. W: Sadowe stosowanie prawa. Red. B. DolnICKI. Katowice 2014.

${ }^{25}$ Wyróżnia się również subsydiarność milczącą, która wynika z relacji merytorycznej, w jakiej pozostają poszczególne przepisy. Twierdzi się, że ma ona zastosowanie do form stadialnych oraz przypadków grup przepisów penalizujących narażanie dobra prawnego na niebezpieczeństwo oraz naruszenie dobra prawnego. Już w latach 70. poprzedniego wieku podniesiono krytykę, że te poszczególne przypadki są rozstrzygane na podstawie zasady konsumpcji. W. Mącior uważał, że wszędzie tam, gdzie mogła mieć zastosowa- 
Konieczne jest przyjrzenie się zasadzie konsumpcji (lex consumens derogat legi consumptae), która polega na tym, że jeden przepis zostaje „skonsumowany”, „pochłonięty” przez drugi ${ }^{26}$. Jest to zasada o charakterze teleologicznym, czyli celowościowym. Dlatego jej stosowanie zależy od przeprowadzonej oceny ${ }^{27}$. Podstawą logiczną dla tej zasady jest stosunek krzyżowania się przepisów (norm), niemniej jednak oznacza to tylko tyle, że $\mathrm{w}$ przypadku pozostawania $\mathrm{w}$ stosunku logicznym interferencji dwóch przepisów (norm), może mieć zastosowanie ta zasada, lecz nie musi ${ }^{28}$. Zdaniem A. Spotowskiego podstawą działania zasady konsumpcji jest „to, że stopień niebezpieczeństwa danego czynu, wyczerpującego znamiona określone $\mathrm{w}$ dwóch przepisach ustawy karnej, oceniany przez pryzmat jednego przepisu jest inny niż stopień społecznego niebezpieczeństwa tegoż czynu oceniany przez pryzmat drugiego przepisu. Warunkiem [...] jest [...], aby stopień społecznego niebezpieczeństwa czynu oceniany przez pryzmat przepisu pochłanianego był znacznie niższy od stopnia społecznego niebezpieczeństwa tegoż czynu ocenianego przez pryzmat przepisu pochłaniającego"29. A. Spotowski uważał, że oceniając społeczne niebezpieczeństwo czynu, należy brać pod uwage elementy podmiotowe i przedmiotowe, które składają się na to pojęcie ${ }^{30}$. Pomijam w tym miejscu zarzuty doktryny dotyczące ustawowego ujęcia społecznej szkodliwości czynu ${ }^{31}$, problem jest złożony i omówienie go wychodzi poza zakres niniejszego opracowania. Pragnę jedynie pokrótce ustosunkować się do propozycji porównywania stopnia społecznej szkodliwości przepisu „pochłaniającego” do przepisu „pochłanianego”. Moim zdaniem stosując zasadę konsumpcji przy zbiegu przepisów, nie powinno się kierować kryterium społecznej szkodliwości czynu. Sztuczne rozdzielenie czynu i dwukrotna ocena przez pryzmat zbiegających się przepisów sugeruje, że dokonujemy oceny in abstracto, a nie in concreto, oraz że mamy do czynienia ze zbiegiem wieloczynowym. W przypadku jednego czynu nie powinno się kierować stopniem społecznej szkodliwości zbiegających się

nie zasada subsydiarności milczącej, może być zastosowana zasada konsumpcji, ale nie odwrotnie - zob. W. MącIor: Zbieg przepisów ustawy jako problem logiczny i prawny. PiP 1975, nr 1, s. 34-35. Inaczej A. Spotowski, który uważał, że subsydiarność milczącą należy rozwijać - zob. A. Spotowski: Pomijany (pozorny) zbieg przepisów ustawy i przestępstw. Warszawa 1976, s. 108 i nast. W pełni podzielam pogląd W. Mąciora.

26 W. Wolter: Reguty wytaczania wielości ocen. Kraków 1961, s. 60 i nast.; A. SPOTOWsKI: Pomijalny (pozorny) zbieg..., s. 123 i nast.; A. MAREK: Prawo karne. Warszawa 2005, s. 225 i nast.

27 W. MĄcior: Zbieg przepisów..., s. 74.

28 A. Sротоwsкi: Pomijalny (pozorny) zbieg..., s. 125.

${ }^{29}$ Ibidem, s. 128.

30 Ibidem s. 131.

${ }^{31}$ Por. O. Sitarz: Czynny żal... i tam powołana literatura. 
przepisów. Inaczej jest w sytuacji zbiegu przestępstw, gdzie również zasada konsumpcji znajduje zastosowanie przy przestępstwach współukaranych uprzednich i następczych. Tam kierowanie się porównaniem stopnia społecznej szkodliwości zbiegających się czynów jest jak najbardziej uzasadnione. Szersze omówienie tematu również wykracza poza ramy niniejszego opracowania. Stosując zasadę konsumpcji, zamiast kryterium porównywania stopni społecznej szkodliwości czynu skłaniam się do poglądu wyrażonego przez P. Kardasa, że zasada konsumpcji znajdzie zastosowanie, gdy przepis „wchłaniający” w pełni oddaje to, co jest opisane w znamionach przepisu „wchłanianego”. Jak zauważa P. Kardas, relacja pomiędzy przepisami jest taka, że jeden z przepisów z punktu widzenia aspektu kryminalno-politycznego odzwierciedla również to, co zostało ujęte w znamionach innych przepisów, zbiegających się do oceny tego samego czynu. Zastosowanie przepisu obejmującego szerszy aspekt zachowania oddaje w pełni zawartość kryminalno-polityczną czynu, co skutkuje brakiem potrzeby powoływania w kwalifikacji zbiegających się przepisów $^{32}$. Ponadto autor ten podnosi, że „powszechnie akcentuje się, że zasada konsumpcji związana jest z oceną dokonywaną in concreto z uwzględnieniem wszystkich czynności związanych z wartościowanym czynem. Stąd też nie sposób wskazać in abstracto grup przepisów, między którymi zbieg byłyby rozstrzygalny już na etapie przekładu przepisów na normy poprzez wykorzystanie zasady lex consumens derogat legi consumptae"33.

Należy również przypomnieć, że podstawą kumulatywnej kwalifikacji jest założenie, że przepisy pozostają ze sobą w stosunku logicznym. Jeżeli pomiędzy nimi zachodzi logiczny stosunek krzyżowania (inferencji - powstaja jakby wspólne pola), to wtedy zakresy tych przepisów tworzą wspólny zakres ze wszystkich zbiegających się znamion przepisów. Jeżeli ten wspólny zakres dawałby możliwość utworzenia nowego przepisu, a przepis taki nie zostałby wprowadzony przez ustawodawcę, wtedy należy skorzystać z kumulatywnej kwalifikacji, jeżeli jeden czyn wchodzi w takie wspólne pole ${ }^{34}$. Jak zauważa W. Wolter, „ustawodawca nie może nastawiać przepisów na wszystkie możliwe wypadki, w których jeden czyn wskazuje znamiona zawarte w więcej niż jednym przepisie, nie może kodyfikacyjnie uwzględniać tego, że przepisy karne mogą się krzyżować, wobec czego możliwe są czyny wchodzące w obręb wspólnego pola. [...] Wyręcza go w tej pracy jeden przepis [...], oddający w ręce sądu złożenie dwóch lub więcej przepisów w jedno przestępstwo"35. Należy

32 P. KARDAs: Zbieg przepisów ustawy w prawie karnym. Warszawa 2011, s. 340.

33 Ibidem.

${ }^{34}$ W. Wolter: Kumulatywny zbieg przepisów ustawy. Kraków 1960, s. 42-44.

35 W. Wolter: Nauka..., s. 339. 
sięgać jedynie po te przepisy, które charakteryzują w sposób wyczerpujący czyn sprawcy. Nie należy stosować tych, które oddają cechy czynu $\mathrm{w}$ innych zastosowanych przepisach. Oznacza to, że kumulatywna kwalifikacja nie powinna zawierać przepisów zbędnych ${ }^{36}$. Jeden czyn sprawcy musi zrealizować znamiona zbiegających się przepisów ${ }^{37}$. Oznacza to, że sprawca zrealizował ich znamiona przedmiotowe i podmiotowe. Przyjęcie takiej koncepcji pozwala na pełne odzwierciedlenie bezprawności czynu sprawcy $^{38}$.

Odnosząc powyższe - $\mathrm{z}$ drobnym zastrzeżeniem odnośnie do porównywania stopnia społecznej szkodliwości - do usiłowania kwalifikowanego, należy rozważyć, czy jeden czyn sprawcy można ocenić przez pryzmat usiłowania, czy też konieczne jest sięgnięcie do kumulatywnej kwalifikacji. Proponuję, żeby w każdym przypadku rozważyć, czy usiłowanie w pełni oddaje obraz czynu, którego dopuścił się sprawca.

Jeżeli celem oceny prawnej zachowania sprawcy jest oddanie jego bezprawia i zostało to osiagnięte przez dokonanie oceny przez pryzmat jedynie usiłowania, nie ma potrzeby sięgania do kumulatywnej kwalifikacji. Jeżeli usiłowanie z punktu widzenia aspektu kryminalno-politycznego odzwierciedla również to, co zostało ujęte $\mathrm{w}$ znamionach innych przepisów, zbiegających się do oceny tego samego czynu, to nie ma potrzeby powoływania w kwalifikacji zbiegających się przepisów. To, czy ta zasada znajdzie zastosowanie (czyli - czy czyn sprawcy zostanie zakwalifikowany jako usiłowanie, a nie usiłowanie kumulatywnie kwalifikowane $\mathrm{z}$ dokonaniem), zależy od indywidualnych cech czynu sprawcy.

Należy również pamiętać o sytuacjach, gdy do istoty usiłowania czynu zabronionego należy popełnienie innego czynu zabronionego. Np. sprawca, który przemocą zmusza drugą osobę do obcowania płciowego, w trakcie usiłowania narusza nietykalność osobistą ofiary. Naruszenie nietykalności osobistej jest koniecznym etapem „iter delicti” zgwałcenia przy użyciu przemocy. W takim przypadku usiłowanie zgwałcenia przy użyciu przemocy w pełni oddaje bezprawie konkretnego czynu sprawcy i nie ma potrzeby kumulatywnej kwalifikacji z naruszeniem nietykalności osobistej. Dotyczy to również przestępstw wieloczynowych. $Z$ tym że moim zdaniem usiłowanie przestępstwa dwuaktowego, gdzie podjęte przez sprawcę czyny nie stanowią z osobna przestępstw, jest zwykłym usiłowaniem, natomiast przestępstwo złożone, gdzie poszczególne elementy typizacji stanowią odrębne czyny zabronione, również należy ocenić jako

36 Ibidem, s. 340.

37 Ibidem, s. 339-340; por. K. BuchałA, A. Zoll: Polskie prawo..., s. 326.

38 W. Wolter: Kumulatywny..., s. 54. 
usiłowanie, a nie usiłowanie kwalifikowane, ponieważ znajdą tu zastosowanie reguły wyłączenia wielości ocen.

Drugą grupę stanowią sytuacje, gdzie zachowanie sprawcy można jednocześnie ocenić jako usiłowanie i dokonanie, a nie znajdują zastosowania reguły wyłączenia wielości ocen, i takie „popełnione” przestępstwo nie jest integralną częścią usiłowania oraz zakwalifikowanie czynu jako usiłowanie nie odda jego całego bezprawia, wówczas należy zakwalifikować czyn sprawcy jako usiłowanie kumulatywnie kwalifikowane z dokonaniem. Usiłowanie kumulatywnie kwalifikowane z dokonaniem będzie miało miejsce w sytuacji, kiedy realizacja znamion "po drodze” innej typizacji nie mieści się w usiłowaniu. Skorzystanie z kumulatywnej kwalifikacji jest konieczne, aby oddać całe bezprawie czynu, a nie z powodu formalnego wystąpienia dwóch przepisów.

W powyższej sytuacji oczywiście należy ustalić, czy sprawca rzeczywiście zrealizował znamiona wszystkich zbiegających się przepisów, w tym stronę podmiotową „dokonania”, które nastąpiło „po drodze” usiłowania. W tym przypadku sprawca musiałby mieć zamiar co najmniej ewentualny. W niektórych przypadkach można przyjąć usiłowanie kumulatywnie kwalifikowane z różną stroną podmiotową (umyślność - nieumyślność), z tym zastrzeżeniem, że usiłowanie będzie objęte umyślnością, a dokonanie jest objęte nieumyślną stroną podmiotową. Ostateczna ocena będzie zależała od konkretnego stanu faktycznego.

Trzecią, odrębną, grupę stanowią sytuacje, gdzie przy usiłowaniu wystąpi czynny żal. Sprawca w zamiarze popełnienia czynu zabronionego swoim zachowaniem bezpośrednio zmierza do dokonania, które jednak nie następuje (usiłowanie), a to „zachowanie” zawiera w sobie realizację znamion innej typizacji, oraz, na podstawie czynnego żalu, sprawca nie poniesie odpowiedzialności za usiłowanie, a jedynie za zrealizowane „po drodze" znamiona innej typizacji, co można ocenić jako niekaralne usiłowanie subsumowane jako karalne dokonanie ${ }^{39}$. W ramach usiłowania sprawca zrealizował znamiona innej typizacji, która staje się podstawą jego odpowiedzialności karnej. Skuteczny czynny żal wyłącza karalność za usiłowanie. Niemniej ten sam czyn sprawcy może być oceniony jako karalne dokonanie innego czynu zabronionego. Sprawca usiłowania zrezygnował ze swojego zamiaru i podjął działania zmierzające do zapobieżenia powstania skutku stanowiącego znamię czynu zabronionego. Jeżeli przyjmuje się, że sprawca swoim zamiarem obejmował spowodowane „po drodze” skutki, to konsekwencją takiego poglądu musi być przyję-

${ }^{39} \mathrm{~W}$ innym miejscu opisywałem tę sytuację jako bezkarne usiłowanie subsumowane jako karalne dokonanie. Względy poprawności językowej przemawiają za użyciem słowa „niekaralne”. Zob. M. ZIELEZnY: Bezkarne usitowanie kwalifikowane... 
cie możliwości oceny zachowania sprawcy przez pryzmat nieskutecznego czynnego żalu z art. 15 § 2 k.k.

W moim przekonaniu konieczność subsumowania takiego stanu faktycznego jako dokonania wynika z dwóch przyczyn. Po pierwsze, czynny żal nie wyłącza bytu czynu zabronionego, lecz wyłączona jest jedynie karalność za usiłowanie. Druga przyczyna jest związana z funkcją sprawiedliwościową prawa karnego. Niekaralne usiłowanie subsumowane jako karalne dokonanie ma na celu ochronę faktycznie naruszonych dóbr prawnych. Jeżeli wymaga się, aby prawo karne reagowało na faktycznie naruszone dobro prawne, to właśnie $\mathrm{z}$ tych funkcji tego prawa wynika powinność zakwalifikowania czynu sprawcy jako karalnego dokonania, z tym że należy pamiętać o możliwości nadzwyczajnego złagodzenia kary na podstawie art. $15 \S 2 \mathrm{k} . \mathrm{k}$.

Reasumując, można oddzielić od siebie trzy różne sytuacje, które zwykliśmy nazywać tzw. usiłowaniem kwalifikowanym. Tym pojęciem można objąć tylko te stany faktyczne, w których zaktualizuje się potrzeba sięgnięcia po kumulatywną kwalifikację, czyli usiłowanie kumulatywnie kwalifikowane $\mathrm{z}$ dokonaniem. Natomiast odrębnym problemem jest sytuacja, w której na podstawie reguł wyłączenia wielości ocen nie będzie uwzględniana kumulatywna kwalifikacja. Ponadto inaczej należy ocenić niekaralne usiłowanie subsumowane jako karalne dokonanie. Te dwie ostatnie grupy stanów faktycznych nie powinny być nazywane usiłowaniem kwalifikowanym.

\section{Bibliografia}

\section{Literatura}

ANDREJEw I.: Prawo karne. Warszawa 1989.

BOJARSKI T.: Polskie prawo karne. Warszawa 2008.

Buchata K., Zoll A.: Polskie prawo karne. Warszawa 1995.

CIEŚLAK M.: Polskie prawo karne. Zarys systemowego ujęcia. Warszawa 1990.

GajDus D.: Czynny żal w polskim prawie karnym. Torun 1984.

GARDOCKI L.: Prawo karne. Warszawa 2011.

GIEZeK J.: Komentarz do art. 13 Kodeksu karnego. LEX nr 28062.

GuBIŃsKI A.: Zasady prawa karnego. Warszawa 1974.

KARDAS P.: Zbieg przepisów ustawy w prawie karnym. Warszawa 2011.

Kodeks karny. Część ogólna. Komentarz do art. 1-31. T. I. Red. M. KRóLIKowsKI, R. ZawıOCKI. Warszawa 2011.

Kodeks karny. Komentarz. Red. T. BOJARSKI. Warszawa 2008.

MAReK A.: Prawo karne. Warszawa 2005.

Mącion W.: Zbieg przepisów ustawy jako problem logiczny i prawny. PiP 1975, nr 1.

Mozgawa M.: Prawo karne materialne. Część ogólna. Warszawa 2011. 
Prawo karne. Red. T. BoJARSKI. Lublin 1994.

Radecki W.: Prawne i moralne oceny czynnego żalu. Pal. 1976, nr 12.

RejMAn G.: Zasady odpowiedzialności karnej. Art. 8-31 KK. Komentarz. Warszawa 2009.

SITARz O.: Czynny żal zwiąany z usiłowaniem w polskim prawie karnym. Katowice 2015.

SPOTоwsкi A.: Pomijany (pozorny) zbieg przepisów ustawy i przestępstw. Warszawa 1976.

ŚwIDA W.: Prawo karne. Warszawa 1989.

WąsEK A.: Kodeks karny. Komentarz. T. I: art. 1-31. Gdańsk 1999.

WOLTER W.: Kumulatywny zbieg przepisów ustawy. Kraków 1960.

Wolter W.: Nauka o przestępstwie. Warszawa 1973.

Wolter W.: Reguły wyłączania wielości ocen. Kraków 1961.

Wróbel W., Zoll A.: Polskie prawo karne. Kraków 2010.

ZIELEZNY M.: Bezkarne usitowanie kwalifikowane jako karalne dokonanie $w$ orzecznictwie. W: Sadowe stosowanie prawa. Red. B. DolnicKI. Katowice 2014.

Zoll A.: Zbieg przepisów określających typy czynów zabronionych o zróżnicowanej stronie przedmiotowej. W: Zbieg przepisów oraz zbieg przestępstw $w$ polskim prawie karnym. Materiały II Bielańskiego Kolokwium Karnistycznego. Red. J. MAJEwsKi. Toruń 2006. 